would never guess so from this kind of interview. Maddox is at his best as a commentator and all that this programme needs to become really worthwhile is to use him in that role while unloading some of the interviewing donkey work on to someone more adept at the task. If the powers that be at the BBC could then be persuaded to ensure that it did not clash with the only regular science programme on television ("Horizon") those of us who have been lobbying for more science programmes would really have something to shout about.

\title{
obituary
}

\section{Sir Robert Waston-Watt}

Sir Robert Watson-Watt, pioneer of radar, died on December 5,1973 . He was 81 years old and had been in poor health for some time.

He obtained his early education in Brechin, his birthplace, and proceeded with a bursary to Tniversity of St Andrews where, at University College, Dundee, he studied electrical engineering. After graduation he was appointed Assistant to the Professor of Natural Philosophy at Dundee, a post which he occupied until 1915 when he became an assistant at the Branch Metcorological Office at the Royal Aircraft Factory, Farnborough.

It was during his service at Farnborough that he took up the study of thunderstorms by means of the radio waves, or atmospherics, emitted by them. After the end of hostilities, work on atmospherics and their relation to meteorological phenomena became the main investigation of the station of which he had been made Meteorologistin-Charge in 1917. He continued in charge of the station after its transfer to the Department of Scientific and Industrial Research in 1921 and its removal to Slough in 1924. In 1927 he became Superintendent of the Radio Research Station set up to absorb the atmospheries work and other radio research of the Department of Scientific and Industrial Research in progress at Slough.

In his early studies of atmospherics one of the main problems was the location of their sources. Although some success on streams of atmospherics was obtained using Bellini-Tosi direction finders, it was Watson-Watt's invention of the instantaneous visual cathode-ray direction finder (CRDF) which enabled the source of a single atmospheric to be found and greatly facilitated the whole investigation.

During the Second World War Watson-Watt's CRDF apparatus was operated by the Meteorological Office as a means of observing the positions of thunderstorms around the British Isles in areas from which no synoptic reports were then received. Similar equipment is still regularly used by the Meteorological Office to help in the production of weather forecasts.

The ability of the CRDF to work on short duration signals found an important application during the Battle of the Atlantic during which ship- and shore-based apparatus was used to locate U-boats from bearings obtained on their brief radio transmissions.

Watson-Watt will, however, be best remembered for his pioneering work in radar. This began early in 1935 when he was approached informally by the Air Ministry for an independent appreciation of the possibility of generating a radio 'death-ray' for use against enemy aircraft. While rejecting the feasibility of such a ray, he reported that the detection and location of aircraft at useful ranges was possible and subsequently submitted a memorandum giving his proposals on how this could be done to Sir Henry Tizard's Committee for the Scientific Survey of Air Defence. After a successful demonstration of the underlying principles he was requested to begin development work along the lines indicated in the memorandom. This he did at Orfordness where the work prospered rapidly and was soon moved to Bawdsey, near Felixstowe.

Appointed Superintendent of Bawdsey Research Station in August 1936 he and his team devoted themselves energetically to those forms of radar, both ground-based and airborne, which were to play such a vital part in the Second World War.

After the successful initiation of radar, Watson-Watt, while continuing to make important technical contributions, found his main activity in cogent advocacy of radar in Whitehall and in stimulating the bureaucratic machine into unwonted activity to provide the material requircments of the research worker and of the coastal stations. These activities led, in 1938, to his appointment as Director of Communications Development, Air Ministry, but soon after the outbreak of war, his talents found more congenial use as
Scientific Advisor on Telecommunications at both the Air Ministry and Ministry of Aircraft Production, and as Vice Chairman of the Radio Board of the War Cabinet.

After the war he retired from Government service to conduct a consultancy business, mainly in North America, which he set up with wartime colleagues.

Amongst the many honours he received were C. B. and Knight Bachelor; he was a Fellow and Hughes Medallist of the Royal Society and held honorary doctorates of St Andrews, Toronto and Laval Universities. He was a Past President of the Royal Meteorological Society and of the Institute of Navigation.

A man of great gifts and wide interests he was a genial, courteous and well-informed companion.

\section{Sir Ronald Holroyd}

SIr Ronald Holroyd, FRS, who died on September 29, was an outstanding industrial scientist. His genius lay not in success as an individual worker, but in a capacity to organise large-scale research projects that were the foundation of important new processes. His field was coal and petroleum chemistry, and he was responsible for developments which were of major national importance during and immediately after the second world war.

Holroyd was born in Yorkshire on April 26, 1904. After going to Holgate Grammar School, Barnsley, he read chemistry at Sheffield University (1921-25). After a short period with the Board of Trade, he joined ICI in 1928. Originally with Brunner, Mond at Winnington, he transferred to Billingham in 1932. In 1947 he was appointed research director of Billingham Division, and five years later joined the ICI Main Board in London, quickly becoming research director (1935). In 1957 he was appointed a Deputy Chairman, and held this position until he retired in 1967 .

At Billingham, Holroyd was partic- 
ularly concerned with the production of liquid hydrocarbons, including petrol, by the hydrogenation of coal and creosote, and a plant was put into operation in 1935. The outbreak of war in 1939 gave new urgency to this process, especially for the supply of aviation fuel, because of the lack of petroleum-refining capacity in Britain. In 1941 a consortium of ICI, Shell, and Trinidad Leaseholds set up a gas-oil hydrogenation plant at Heysham, and in the latter years of the war some half million tons of aviation base spirit was produced in Britain annually. Among technical problems overcome was that of increas- ing the octane rating, partly by increasing the aromatic content and partly by additives such as tertiary butyl benzene (Victane) and monomethyl aniline. This was of crucial importance in enabling Spitfires to eatch German V 1 rockets. Apart from their intrinsic importance, these developments resulted in an accumulation of knowledge and experience of hydrocarbon chemistry, which was invaluable in the post-war chemical revolution when petroleum almost wholly superceded coal-tar as a raw material.

An off-shoot of this work was the development of analytical techniques for hydrocarbons, especially infra-red and ultraviolet spectroscopy. Analysis of fuel from shot-down enemy aircraft threw much light on the German oil supply situation. In the closing stages of the war, Holroyd led several teams which went to Germany to investigate oil and aviation fuel developments there.

Holroyd's contributions were widely recognised. He was elected Fellow of the Royal Society in 1960, and was knighted in 1963. He was an honorary graduate of Oxford, Sheffield, Hull, and Trinity College Dublin. In 1958 he was awarded the Castner Medal of the Society of Chemical Industry, of which he was President 1965-7.

\section{matters arising}

\section{Mesozoic rocks from the Labrador sea}

Because of the great interest, both academic and commercial, in the samples reported by Johnson et $a l^{1}{ }^{1}$, additional stratigraphic analyses were conducted in Pau, France, by Aquitaine Company of Canada (Table 1). These analyses were concentrated on the nannofossils; especially the coccoliths ( $\mathrm{G}$. Chennaux and S. Mulle, unpublished).
As noted by Chennaux and Mulle (Tabe 1) the samples show a heterogeneity of ages ranging from Mesozoic to Recent. The Mesozoic nannofossils are in a poor state of preservation in contrast to well preserved Tertiary nannofossils, which supports the younger age. The presence of Mesozoic spores and pollens ${ }^{1}$ are therefore assumed to be reworked organic debris deposited in the prograding Tertiary sequences.

A Tertiary age for these samples would be in agreement with seismic ve- locities from the outer Greenland shelf (N. J. McMillan, personal communication). An Oligocene date plots along a more normal subsidence rate of $30-40$ $m$ per m.y. (ref. 1, Fig. 2).

These revised ages for Greenland samples suggest that the Mesozoic ages reported from the Labrador continental margin $^{2}$ may need revision too.

We thank J. Aubert, F. Deres, C. Boulovard, G. Peniguel, and C. Poumot all of Centre de Recherches de Societe Nationale des Petroles d'Aquitaine, Pau,

TABLE 1 Revised data on South-west Greenland dredge samples

\begin{tabular}{|c|c|c|c|c|c|}
\hline & & Age of as & ociations & Age proposed by Johnson et al. ${ }^{1}$ & \\
\hline Sample No. & Position & Nannofossils & Palynoplanktology & Palynoplanktology & Revised age \\
\hline 32 & $\begin{array}{l}60^{\circ} 04.8^{\prime} \mathrm{N} \\
46^{\circ} 44.0^{\prime} \mathrm{W}\end{array}$ & $\begin{array}{l}\text { Oligocene (and remains } \\
\text { of Lower Cretaceous) }\end{array}$ & $\begin{array}{l}\text { Lower Palaeozoic } \\
\text { Triassic } \\
\text { Cretaceous to Jurassic }\end{array}$ & $\begin{array}{l}\text { Upper Cretaceous (and } \\
\text { Jurassic remains) }\end{array}$ & Oligocene \\
\hline 37 & $\begin{array}{l}60^{\circ} 04.6^{\prime} \mathrm{N} \\
47^{\circ} 10.5^{\prime} \mathrm{W}\end{array}$ & $\begin{array}{l}\text { Oligocene to } \\
\text { Lower Miocene }\end{array}$ & $\begin{array}{l}\text { Undetermined } \\
\text { Probably Recent }\end{array}$ & $\begin{array}{l}\text { Upper Cretaceous (Albian or } \\
\text { younger) (and Jurassic remains) }\end{array}$ & Oligocene \\
\hline $43 \mathrm{~A}$ & $\begin{array}{l}63^{\circ} 34.3^{\prime} \mathrm{N} \\
52^{\circ} 57.0^{\prime} \mathrm{W}\end{array}$ & Oligocene & Lower Cretaceous & Upper Cretaceous & Oligocene \\
\hline $43 \mathrm{~B}$ & $\begin{array}{l}63^{\circ} 34.3^{\prime} \mathrm{N} \\
52^{\circ} 57.0^{\prime} \mathrm{W}\end{array}$ & Probably Eocene & $\begin{array}{l}\text { Cretaceous? } \\
\text { Triassic? } \\
\text { Carboniferous? }\end{array}$ & $\begin{array}{l}\text { Upper Cretaceous (Turonian-- } \\
\text { Senonian Lower) (and } \\
\text { Jurassic and Upper } \\
\text { Carboniferous relics) }\end{array}$ & Eocene \\
\hline 56 & $\begin{array}{l}61^{\circ} 35.5^{\prime} \mathrm{N} \\
50^{\circ} 37.1^{\prime} \mathrm{W}\end{array}$ & $\begin{array}{l}\text { Eocene-Oligocene (and } \\
\text { Jurassic remains) }\end{array}$ & $\begin{array}{l}\text { Lower Cretaceous } \\
\text { Recent? } \\
\text { Triassic }\end{array}$ & $\begin{array}{l}\text { Upper Cretaceous (and Jurassic } \\
\text { and Upper Carboniferots } \\
\text { relies) }\end{array}$ & $\begin{array}{l}\text { Eocene to } \\
\text { Oligocene }\end{array}$ \\
\hline $59 \mathrm{~A}$ & $\begin{array}{l}61^{\circ} 53.0^{\prime} \mathrm{N} \\
50^{\circ} 45.0^{\prime} \mathrm{W}\end{array}$ & $\begin{array}{l}\text { Middle Eocene to } \\
\text { Oligocene }\end{array}$ & Lifeless & $\begin{array}{l}\text { Upper Cenomanian to Lower } \\
\text { Turonian }\end{array}$ & Oligocene \\
\hline $59 \mathrm{~B}$ & $\begin{array}{l}61^{\circ} 53.0^{\prime} \mathrm{N} \\
50^{\circ} 45.0^{\prime} \mathrm{W}\end{array}$ & Lifeless & $\begin{array}{l}\text { Lower Cretaceous } \\
\text { Triassic }\end{array}$ & $\begin{array}{l}\text { Upper Cenomanian to Lower } \\
\text { Turonian }\end{array}$ & \\
\hline $62 \AA$ & $\begin{array}{l}62^{\circ} 35.0^{\prime} \mathrm{N} \\
51^{\circ} 35.0^{\prime} \mathrm{W}\end{array}$ & Lifeless & Triassic to Cretaceous & $\begin{array}{l}\text { Pliocene to Recent (and } \\
\text { Cretaceous, Jurassic and } \\
\text { Palaeozoic) }\end{array}$ & $\begin{array}{r}\text { Pleistocene? } \\
\text { to Recent }\end{array}$ \\
\hline $62 \mathrm{~B}$ & $\begin{array}{l}62^{\circ} 35.0^{\prime} \mathrm{N} \\
51^{\circ} 35.0^{\prime} \mathrm{W}\end{array}$ & Probably Recent & $\begin{array}{l}\text { Recent? } \\
\text { Lower Cretaceous } \\
\text { Triassic }\end{array}$ & Turonian & $\begin{array}{l}\text { Pleistocene? } \\
\text { to Recent }\end{array}$ \\
\hline 65 & $\begin{array}{l}63^{\circ} 07.5^{\prime} \mathrm{N} \\
52^{\circ} 17.8^{\prime} \mathrm{W}\end{array}$ & Lower Palaeocene & Lower Cretaceous & $\begin{array}{l}\text { Jurassic lower (Bajocian or } \\
\text { Pliensbachian) and unde- } \\
\text { termined }\end{array}$ & $\begin{array}{l}\text { Lower } \\
\text { Palaeocene }\end{array}$ \\
\hline 69 & $\begin{array}{l}64^{\circ} 25.0^{\prime} \mathrm{N} \\
52^{\circ} 53.0^{\prime} \mathrm{W}\end{array}$ & $\begin{array}{l}\text { Tertiary (and remains } \\
\text { of Cretaceous) }\end{array}$ & Undetermined & $\begin{array}{l}\text { Palaeocene (and Jurassic } \\
\text { remains) }\end{array}$ & Palaeocene \\
\hline
\end{tabular}

